\title{
Assessment of Climate Change Impacts and Adaptation Measures in the Kapilbastu District of Nepal
}

\author{
Govinda Bhandari* \\ Environment Professionals’ Training and Research Institute Pvt. Ltd., Kathmandu, Nepal \\ *Corresponding author: govindabhandari84@yahoo.com
}

Received June 14, 2013; Revised August 29, 2013; Accepted August 29, 2013

\begin{abstract}
This research was carried out in Niglihawa, Hathausa, Barkalpur and Dhankauli Village development committee of Kapilbastu district to assess the impacts of climate change in the livelihoods of people. A semistructured questionnaire was prepared for the questionnaire which was tested during the field visit. Almost all respondents reported change in climate and farming system in their locality. Respondents experienced erratic rainfall pattern, decreased length of winter, increased frequency and length of droughts associated with decrease in water sources in recent years. New invasive weeds have appeared. Farmers were forced to adopt new cultivars and change in planting time to adapt with changing conditions. Incidence of plant diseases and natural hazards in recent years are major threats to livelihood. The study found that people have started adaptation measures autonomously. Adoption of new varieties, construction of stone walls and local irrigation canals, cultivation of cash crops were the major adaptation measures observed. People have started protecting watershed to retain the water resources, rehabilitating traditional ponds/water bodies, promoting afforestation and conservation programmes and taking alternative measures to increase irrigation efficiency to cope with these impacts.
\end{abstract}

Keywords: climate change, adaptation measures, Kapilbastu, Nepal

Cite This Article: Govinda Bhandari, “Assessment of Climate Change Impacts and Adaptation Measures in the Kapilbastu District of Nepal.” Applied Ecology and Environmental Sciences 1, no. 5 (2013): 75-83. doi: 10.12691/aees-1-5-2.

\section{Introduction}

Due to climate change and the rising temperature, Nepal could face drier phases during dry seasons with wetter monsoon with chances of flooding and landslides during rainy seasons with subsequent impacts on agriculture and livelihoods [1]. Climate is an essential factor that has direct effects on agricultural production $[2,4,16]$. Studies on temperature trend in Nepal have identified increasing trend in annual mean and annual maximum temperature in high altitude more than that of lower altitude [3].

Climate change has been a topic of discussion in Nepal due to its increasing stress on water resources and other climate-sensitive resources thereby affecting agricultural production, food security and livelihood [4,7,13,15]. In recent years, farmers are concerned about the climatic change and are trying to adapt through technological innovations in response to climate change at their disposal [5]. Farmers have changed their cropping pattern as per the climatic adjustments and prioritized the use of organic manure rather than chemical fertilizers $[6,18]$. Improved varieties of seeds are also being introduced in their farming $[5,6,18]$.

Observations of regional and seasonal variation at different part of the country resulted high rainfall regions and seasons are recording increases in precipitation and becoming wetter, whereas low rainfall regions and seasons are recording decreases in precipitation and becoming drier [9]. The water springs in the mid Hills of Nepal have been drying up in the recent past [10].

Climate change refers to any change in climate over time, whether due to natural variability or as a result of human activity [11]. Climate change is expected to affect the agricultural production, thereby affecting the livelihood and food security in poor rural parts of developing countries $[2,12,16]$. In Nepal, the temperature has been increased by $1.8^{\circ} \mathrm{C}$ during last 32 years and the average temperature increase was recorded as $0.06^{\circ} \mathrm{C}$ per year [17]. Warming and rising of temperature in the higher altitude has benefitted some households such as growing maize, and green vegetables [18]. It is a long-term change in the statistical distribution of weather pattern, including average temperature and rainfall over periods of time. Climate change is increasingly accepted as the major issue facing the globe.

The population of Nepal is less than $0.4 \%$ of the world population and is responsible for only about $0.025 \%$ of annual greenhouse gas emissions [20]. It also suggested that precipitation is likely to be more uncertain and that storm intensity will increase [21]. Temperature rise in these areas increase the rate of snow and glacier melt, releasing a higher volume of water to flow into lower region. From the trend observed between 1976 and 2005 it is expected that the regions with already high precipitation will receive more rainfall and those with low precipitation 
will see further decrease [22]. All Nepal and regional precipitation series showed significant variability on annual and decadal time scales [24]. It is reported that all Nepal temperature is increasing steadily and 32 years temperature data analyzed showed about $1.8^{\circ} \mathrm{C}$ increase from 1975 - 2006 and in 2006 was reported warmest year in record [25]. Climate change scenarios for Nepal showed considerable convergence on continued warming, with country averaged mean temperature increases of $1.2{ }^{\circ} \mathrm{C}$ and $3{ }^{\circ} \mathrm{C}$ projected by 2050 and 2100 [26]. Nepal's share in climate change (CC) is negligibly small.

Agriculture is the mainstay of Nepalese people which contributes nearly 33\% of Nepal's GDP and supports the livelihoods of more than $86 \%$ of the population. The impact of climate change can be much greater for indigenous communities living in the more remote and ecologically fragile zones and relying directly on their immediate environments for subsistence and livelihood [27]. Climate change is a phenomenon due to emissions of greenhouse gases from fuel combustion, deforestation, urbanization and industrialization resulting variations in solar energy, temperature and precipitation [28]. Nepal has already encountered some of the adverse impacts of climate change. The recently observed extreme weather events between 2006-09 including droughts and floods have significantly affected food production in Nepal [29]. Lower level of awareness to disasters and climate change and its adaptation and mitigation options are associated with higher vulnerability [30].

The rainfall pattern is also experienced as inconsistent with higher intensities of rain and less number of rainy days creating long drought for some time and heavy rain in some other periods. Changes in hydrological cycles and the depletion of water resources are the top challenges facing Nepal in context of climate change. Climate Change is increasingly becoming an emerging issue in the Nepalese context and is viewed as one of the major challenges in the overall development scenario although its total greenhouse gas emission share is negligible compared to global community.

Adaptation is the adjustment in natural or human systems in response to actual or expected climate stimuli or their effects, which moderated harm or exploits beneficial opportunities. Adaptation refers to the measures taken in response to climate change, to reduce the adverse impacts or to take advantage of opportunities offered by such changes.

Adaptation measures can be reactive or anticipatory. Reactive adaptation measures are implemented in response to current climate variability and observed impacts. Anticipatory adaptation measures, on the other hand, are undertaken before impacts are observed to reduce exposure to future risks. Given the uncertainty surrounding climate change, the implementation of anticipatory measures is challenging, as they require indepth information and knowledge about climate change. Adaptation measures may also be classified as: (i) short term or long term (ii) technological and managerial (iii) sectoral, cross-sectoral or multi-sectoral (iv) horizontal or vertical (v) macro, meso or micro scales.

The Government of Nepal has prepared a National Adaptation Program of Action (NAPA) 2010 and National Framework on Local Adaptation Plan for Action (LAPA) 2012 as national documents to guide climate adaptation in the country. Many activities are underway supported by a range of development partners. The non-government sector has also piloted a range of small-scale adaptation actions. However, awareness of climate change at the national, district and community level is still a challenge as is coordination of the many actors.

The overall objectives of the study are to identify how climate changes are observed by poor and excluded communities particularly in the sectors like: agriculture, water, forest and biodiversity, and look at the impacts and effects made by these changes in the communities and their community based adaptation strategies in Kapilbastu district of Nepal.

\section{General Description of the Study Area}

The Kapilbastu district is situated at the height of 93 to 1491 meters from sea level. Geographically, the district can be divided into plain low lands of Terai and low chure Hills. The latitude is $27^{\circ} 32^{\prime} \mathrm{N}$ and longitude is $83^{\circ} 3^{\prime} \mathrm{E}$.

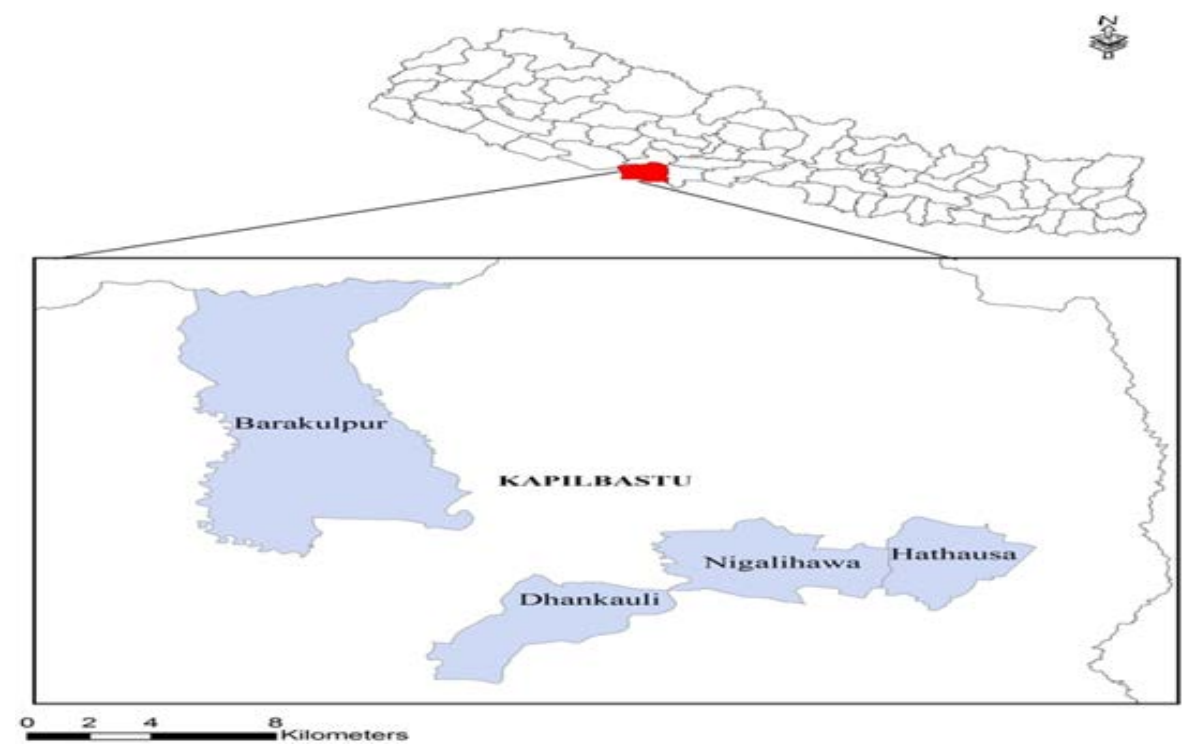

Figure 1. Map of Nepal and location of studied VDCs in Kapilbastu district 
Kapilbastu has a humid, subtropical climate. Its average annual temperatures range from $25^{\circ} \mathrm{C}-19^{\circ} \mathrm{C}$ with a maximum of $43^{\circ} \mathrm{C}$ in the summer to a minimum of $4.5^{\circ} \mathrm{C}$ in the winter. Twenty five years of temperature record in Kapilvastu shows that there is increasing trend of temperature with $0.0216^{\circ} \mathrm{C} /$ year. Its average annual rainfall is $1,850 \mathrm{~mm}$, about $80 \%$ of which falls during the monsoon season, from mid-June to mid-September. Various lakes and ponds, including the Ramsar wetlands site Jagadishpur Reservoir, are located here and its major rivers include the Banganga, Arra, Aghiya and Surahi. Groundwater is the major source for drinking water in Kapilbastu.

Therefore, the research was conducted in Niglihawa, Hathausa, Barkalpur and Dhankauli Village development committee (VDC) of Kapilbastu district to know about the climate change impacts and adaptation measures of the area.

\section{Methodology}

The study began with a review of literatures to understand the differing contexts and background of the seclected study area. This included the identification of reports detailing climate change adaptation programmes and local practices. This was followed by field visit to the different VDCs of the district and conduct semi-structured interview and key informant interview to the government staffs, Non Government Organization staffs, Community Based Organization staffs, local school teachers and practitioners/farmers. Field investigations and interviews were undertaken in between June-July 2012 for the assessment of impact of climate change in agriculture and livelihood. A questionnaire was made and completed at the site discussing with the local farmers. The questions were targeted so as to collect information about 1 . Climate change and 2. Adaptation measures in the study area. Some of the major questions that were asked are presented below. Moreover, resource poor and indigenous people were given the first priority in sampling for the primary data collection. Face to face interview was done for the data collection. Secondary information was collected from Central Bureau of Statistics, District Agriculture Development Office and Department of Hydrology and Meteorology.

\section{Climate change (CC)}

Is the climate warming over the last 30 years?

Is the precipitation pattern changing (intensity, quantity, time)?

Is there any increase in dry period?

Are climatic hazards increasing?

Does a hazard have any consequences on your lives or households?

Have you ever noticed any change of water resources in your locality?

Have you heard/understood about climate change?

In your opinion, what are the reasons behind climate change?

Have you noticed any changes on plant and animal due to climate change?

Have you faced any new disease due to climate change?

\section{Adaptation measures}

What are the effects of CC on farming? (If yes, what are they and how/why? And what you did?)
Is there any change of rainfall available which affects your crops?

Is there any crop which you did not plant 30 years ago, planting now?

Is there any crop which you plant 30 years ago, not planting now?

Is there any change in cropping season, planting and harvesting?

Are there any problems due to climate change?

Have you planted any cash crops by reducing agricultural crops? If yes why and what?

Mention the adaptive mechanism to cope with climate change?

Are you satisfied with the adaptation measure that you follow?

In your opinion, what are the ways to minimize the effects of CC?

Do you want to suggest any thing?

\section{Agricultural Production}

Since long, Nepal is considered one of the agriculture dominated countries and livelihood of the people is entirely dependent on agriculture. Food, the basic need for lives, is also acquired from agriculture. Unfortunately, this sector is particularly vulnerable to the vagaries of the weather. Temperature, humidity, solar radiation and precipitation are important climatic factors for crops. Permanent changes in these factors can lead to failure of crops and subsequent low crop production. Extreme climatic events such as intense rainfall causing flooding and landslides, droughts and other stress are undesirable. The associated crop failure also invites famine. Therefore, whether it brings increasing floods and storms or worse drought, climate change has been havoc for poor farmers, jeopardizing their livelihoods and threatening their food security in the long run. With staggering increase in population and food demand, even a slight decline in annual food production is a matter of great concern in the country like Nepal. This sector is adversely affected by the loss of top fertile soil due to soil erosion, landslides and floods. Soil loss is a major cause of decline in agriculture production and the negative effects of climate change may further aggravate this situation. The agriculture sector has many challenges. First, numerous studies highlighted that across the country, over half of all households rely on less than 0.5 hectares ( 0.67 ha equals 1 bigha) of land to support each family of around six members. Second, the development of agriculture is still in subsistence level. Third, limited crops are the sources of food security. Cereal crops including Oryza sativa L. (paddy), Triticum aestivum L. (wheat), Zea mays L. (maize), Eleusine coracana L. (millet), Hordeum vulgare L. (barely) and Fagopyrum esculentum (buckwheat) are the mainstay of Nepal's agriculture [19]. Paddy in the Terai and Maize, Wheat and Barley in the Hills are the common crops to grow. Millet is a relatively minor cereal. The average yield (1975-2003) of Paddy, Maize, Millet, Barley and Wheat is $1825 \mathrm{Kg} / \mathrm{ha}, 1775 \mathrm{Kg} / \mathrm{ha}, 963 \mathrm{Kg} / \mathrm{ha}, 896 \mathrm{Kg} / \mathrm{ha}$ and $1427 \mathrm{Kg} /$ ha respectively.

\subsection{Climate Change Impacts on Agriculture}


Crops are very sensitive to climate change and its impact is reduction in yield. Rise in temperature has a negative effect on maize as well as wheat and mustard. However, scientific communities believe that changes in temperature and rainfall are creating favourable environments for pests, diseases and invasive species to emerge, spread and encroach on agriculture and forestlands [23]. The increased impacts of climate change put the agricultural sector at the central point of discussion globally since the sector contributes to global climate change as well as can be affected by the changing climate $[2,4,12,13]$.

The production of other winter crops such as cereal, pulses, vegetables, fruits etc is also reduced due to changes in the climate particularly due to longer drought and erratic rain. In the recent years, people have to observe many unidentified diseases in agricultural crops. Some of the popular diseases in Barley, Millet, Paddy, Maize and Wheat include Barley stripe, Cercospora leaf spot, Blast, Fusarium kernel rot and Leaf blight that are caused by Pyrenophora graminea, Cercospora penniseti, Pyricularia oryzae, Fusarium moniliforme and Helminthosporium sativum respectively.

The erratic rain in the recent years has resulted more landslide and erosion cases in the Hills. Top soil is considered very fertile because people treated this part of soil every year with compost manure. Therefore, soil loss is a major cause of decline in agriculture production in the Hills and its effects is negative particularly in yield. The germination and growth rate are affected.

\section{Hydrology}

Water is the largest natural resource of Nepal. The country's water requirements cover drinking water and personal hygiene, religious activities, agriculture, industrial production, hydropower generation, and recreational activities such as swimming and fishing. There is a growing pressure on water resources due to the growth of the population, expansion of irrigation systems for increasing agricultural production. Like other sectors, the changing patterns of climate in recent decades have hampered the water resources sector severely.

\subsection{Climate Change Impacts on Water Resources}

Glaciers, ice, and snow cover $17 \%$ of the Greater Himalayan region and are receding more rapidly than the world average $[8,11]$. The rate of retreat has increased in recent years $[14,31]$. The Landsat imageries clearly show the decline in the snow and ice coverage during the last twenty-five years. If this trend continues, it will have severe impact on the hydrological regime in this region. Impact on water resources was found very high which ultimately affect on all sectors such as agriculture production, drinking water supply, hydropower, water induced disaster as well as forest and biodiversity. Anthropogenic activities as well as climatic uncertainties in this region showed that there would be more water stress in all sectors in future during winter and summer season and flooding, landslides and river bank erosion in rainy season. This changing precipitation pattern indicated that the drought period was becoming longer; delayed monsoon however, there was no definite trend in the annual precipitation amount.

\section{Results and Discussion}

Some of the pertinent issues shared by the people during study are presented below. We got more information on our objectives from the respondents of Niglihawa VDC and Barkalpur VDC.

\subsection{Afforestation Activities to Combat with Increasing Temperature and River Bank Erosion}

It is observed in Nigalihawa, Kapilvastu. Due to high temperature the trees of the community forests as Jharana community forest (JCF) and Sagarhawa community forest (SCF) of the VDC are drying. The unidentified diseases and thick fog also hamper the growth of forest resources. For e.g., Dalbergia sissoo (Sisau) and Morus alba (Kimbu) are badly affected by diseases. Many hectors of Sisau forest has now completely dried up. The growth rate of forest resources has declined. Due to less rain in the recent years, stem of Sal trees is found hollow.

The local inhabitants have raised the trees like Shorea robusta (Sal) and Dalbergia sissoo (Sisau) in cooperation with district forest office. Some local clubs have planted trees near the river bank of Banganga river to check river bank erosion. Farmers believed that the afforestation was done to increase forest cover in community forests with a belief that forest also help to combat with increasing temperatue.

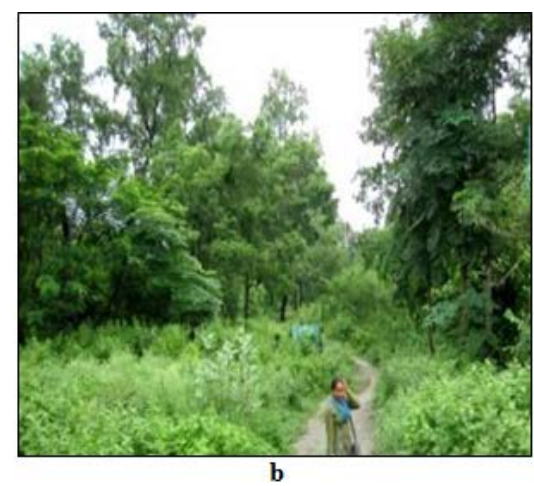

Figure 2. a. Interview with a local farmer; b. Afforestation in SCF 


\subsection{Change in Agriculture Practices and Bedding Farming}

It is observed in Nigalihawa, Kapilvastu. The visible but surprising phenomenon like much flowering and poor fruiting in the fruits and vegetables was observed by local people in the recent years in the study areas. They have no idea about its root causes but they argued that the changing climatic condition is the main reason.

People have been motivated to use pesticides and insecticides in the fruits and vegetables in order to resume the flowers. Use of pesticides and insecticides increases the number of flowers. Due to irregular rainfall and high temperature paddy has been substutited by vegetables as Phaseolus vulgaris (Green bean), Trichosanthes cucumerina (Gourd) and Solanum melongena (Brinjal). Inaddition, cereals like Eleusine coracana (Millet) and Fagopyrum esculentum (Buckwheat) are also grown. Crops like Allium cepa (Onion), Allium sativas (Garlic) and Momordica charantia (Tite karela) are also grown for

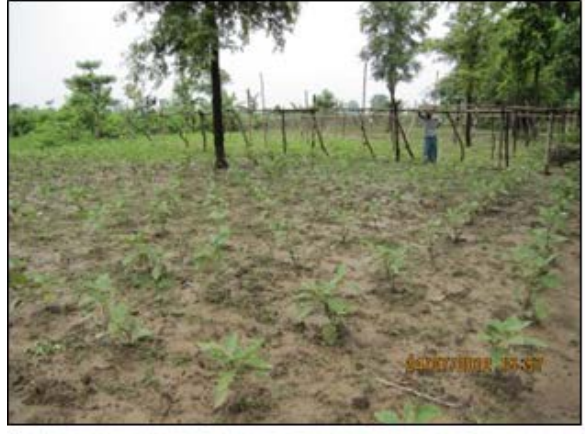

a higher yield. For the cultivation of Allium sativas (Garlic), farmers preferred Satrasaya local due to its attractive quality but they did not prefer Bhote lasun though it produced higher yields. Burning of garlic leaves starting from the tip towards leaf base is serious problem that cause premature drying of leaves and reduced yields.

As the local varieties of paddy needs much water as irrigation, people are compelled to use hybrid varieties of paddy after 1981. Additionally, people are compelled to change seeds every year because second generation seed couldn't work properly. Changing rainfall patterns and higher temperatures have forced people to adopt short ripen varieties and switch to more expensive hybrid crops.

During the rainy season, there is a problem of water logging. Roots of the vegetables get decayed. So, in order to protect vegetable from excessive water caused due to intense rainfall, bedding farming has been adopted. Each bed is of 6 inches height and $50 \mathrm{cms}$ width (in each bed). Excessive water in the field is drained out from the side of the bed.

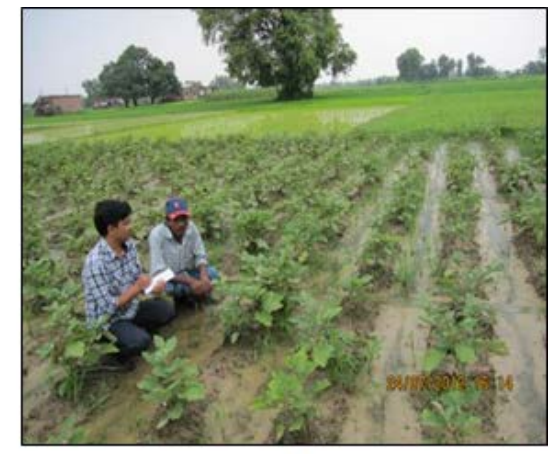

b

Figure 3.a. Shift from paddy to vegetable farm; b. Bedding farming practices

\subsection{Use of Bio-Pesticides to Control Pests}

It is observed in Nigalihawa, Kapilvastu. People said that high moisture creates a favourable environment for the growth of fungal and bacterial diseases in the crops. People repeatedly expressed that the explosion of crop diseases is increasing due to excess use of chemical fertilizer, pesticides and insecticides. Poor rain and longer droughts are other reasons as perceived by local people. Bean blights, caused by one or more species of bacteria has increased in the VDC. Under favorable weather conditions, these bacteria can spread rapidly through a field causing defoliation and pod damage. For e.g.,
Xanthomonas phaseoli (Common Blight) also known as Piliya locally in Green beans in which beans get yellowish and ultimately die. On the other hand, people opined that the production of Brassica juncea (Mustard), Solanum tuberosum L. (Potato) are reduced due to excess use of pesticide and insecticide. Phytophthora infestans (Late blight) is the disease for potato.

Farmers use cow milk on those crops. Boiled juice of Saccharum officinarum L. (Sugarcane), leaves of Azadirachta indica (Neem), Nicotiana tabacum (Tobacco) and cow urine are mixed together and boiled. This boiled liquid is then sprayed in the affected plants to control pests. It is widely used in the the locality.

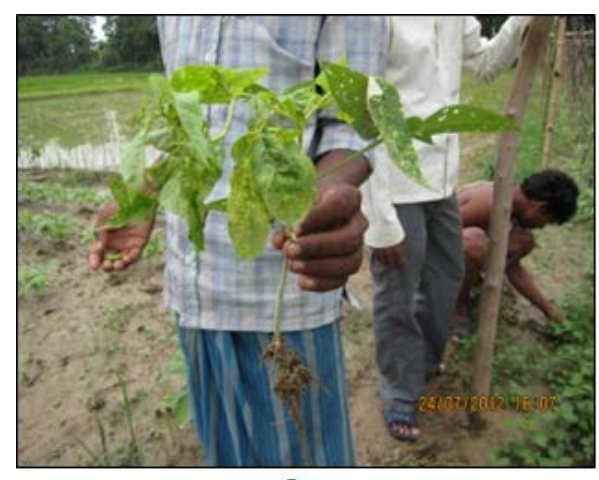

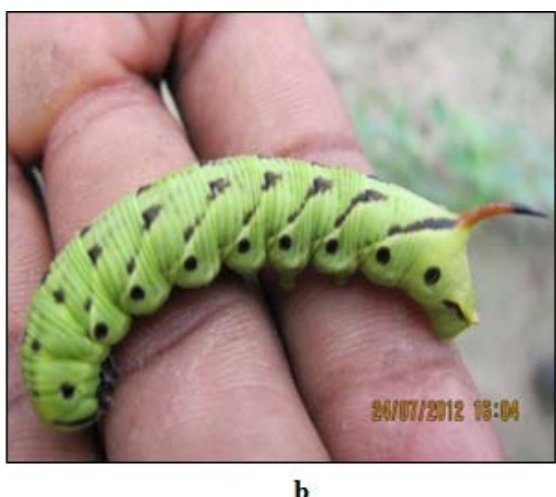

b

Figure 4. a. Piliya disease in green beans; b. Pest causing Piliya 


\subsection{Conservation of Jagdishpur Lake}

It is observed in Nigalihawa, Kapilvastu. Due to climate change the farmers faced floods from farmers managed irrigation systems in the Jagadispur Reservoir. Due to low cost and based on the indigenous technology, people have been operating these systems since generation. But now, these systems are perceived to be at risks due to climate change. They get flood sometimes in rainy seasons from lakes whereas drought and low water level in the ponds in summer season and get loss of their huge property.

Jagadispur reservoir lies in ward no. 1 of Niglihawa VDC in an area of 157 ha. The concrete dam was constructed in 1998 with the support of the Department of irrigation. The dam was constructed for irrigation purpose by rock-fill dike. It runs from north to south from the centre of the reservoir. The eastern part has shallow water body whereas the western part of the reservoir is deeper and completely covered by water. After the construction of dam, the water of this reservoir is used to irrigate agricultural land in 22 VDCs of Kapilvastu. Water is allowed to enter inside the reservoir from the inlet at Laxman Ghat. Optimum amount of water is allowed to enter from inlet to avoid bursting of dam. The irrigation system is managed by the Kapilvastu District Irrigation Office. They have installed water gauge to measure level of water. Conservation activities like afforestation were done by the local people to store more water in the lake and used for irrigation in agricultural field. Maintenance of water level and utilization of pond water for irrigation is done by constructing an irrigation canal. Since it has been constructed predominantly for irrigation purpose, water level fluctuates according to the demand for irrigating cultivated land. To conserve water in the lake, local people have planted sisso around the reservoir to recharge ground water. This afforestation practices increases the level of water in the reservoir. This reservoir is also used for fish farming and increse the attraction of migratory birds. In a nutshell, the Jagadish reservoir is on the Ramsar sites of Nepal - has been extensively used for irrigate major cereals, and solve the problem of water scarcity in that area.

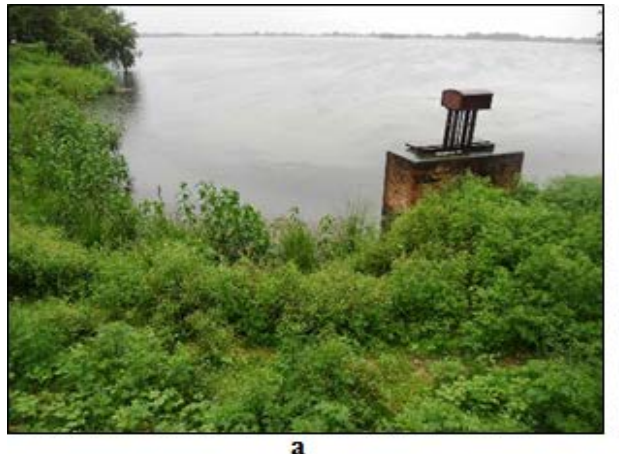

a

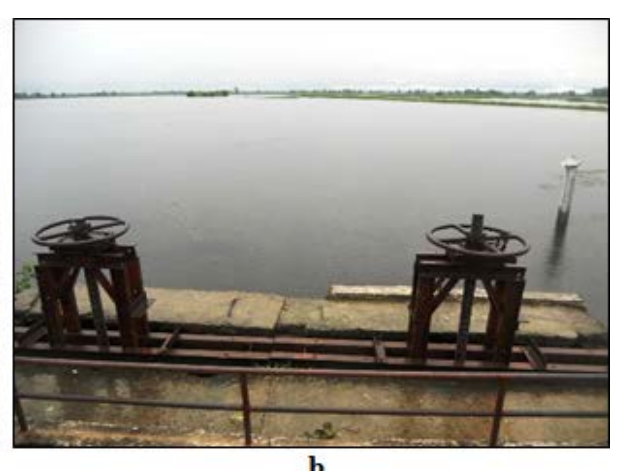

Figure 5. a. Jagdishpur lake; b. An outlet to pass out excess water

\subsection{Change in Rice Species}

It is observed in Hathausa, Kapilvastu. Due to delayed monsoon and untimely rainfall there are intensive downpours and reduction in yields. This results dryness in some areas and excessive rain in other areas. Due to reduction of monsoon season/period by 1.5 month, the cultivation of long period of monsoon crops is not feasible in the changed context in the project areas. As the rain starts late and stop early, people are unable to cultivate long variety of paddy like: Masino Dhan with the genotypes Sawamansuli, Mansuli, Basmati and Kala

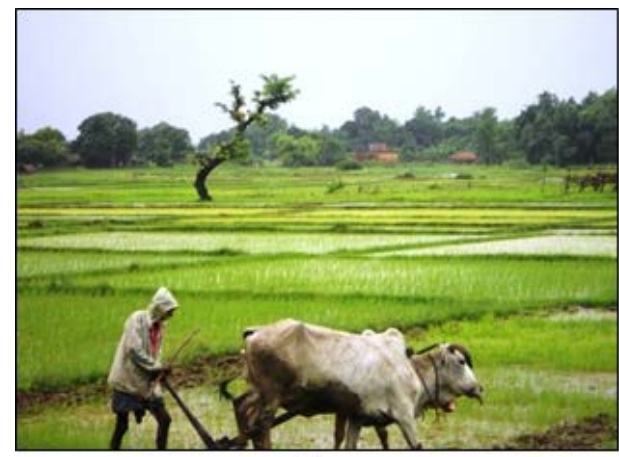

a nimak, Aanadi etc. Rainfall patterns have hindered the growing of long-season local indigenous varieties of crops.

To tackle this the farmers left growing Masino Dhan and have been growing Moto Dhan with the genotypes Radha-4 (IR 8423) and Osan which become ready within 125 days with potential grain yield of 6.0 t/ha and average yield of $3.0 \mathrm{t} / \mathrm{ha}$. It has shown field resistant to blast and bacterial blight. So that they can harvest their crops much earlier before flood and prevent the crops from being washed away by the floods. The short duration Raphanus sativus (Radish) and Daucus carota (Carrot) are common in these days. High yielding off season varities includes Mino early, Japanese white, Tokinashi and 40 days. Among them 40 days is quite famous among farmers.

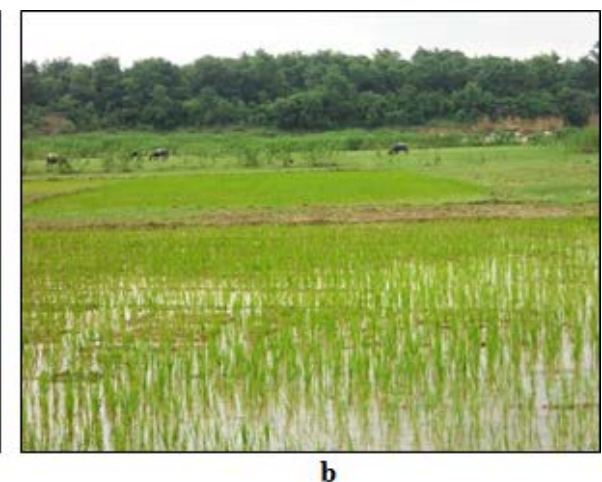

Figure 6. a. IR 8423; b. Moto dhan (Osan) 


\subsection{Shift from Agriculture to Livestock Farming}

It is also observed in Hathausa, Kapilvastu. The yield has become unpredictable due to climate change effects. Grazing land are also disapperaing.

With the changing pattern of climate, people prefer to raise improved variety of livestock instead of local. Murrah buffaloes indigenous to India, which are well adopted from terai to high hills have been producing at higher level than the indegenous breeds. They have been widely used in improving the productivity of indigenous breeds interms of milk production. Farmers preferably feed lacting animals and grazing calves on posilo and obhano fodders. Bos primigenius (Cow) and Bubalus bubalis (Buffalo) varieties of improved livestock are common. More milk giving livestock are popular because selling milk is very easier because of dairy development. With the few numbers of livestock, there is no need of grazing land. Stall feeding practice is largely practiced. They provide local grasses to livestock to get more milk. There is increasing trend of replacing unproductive or indigenous livestock with improved varieties of livestock. Similarly, cultivating new varieties of grass and fodder in private land is also popular.

\subsection{Bagar Farming}

It is observed in Barakulpur and Dhankauli, Kapilvastu. Due to climate change the activities like floods are occurring every year in the rivers of Terai. The banks of the Banganga river in the Kapilvastu district in Nepal were degraded due to frequent floods and subsequent land degradation. Farmers report that the river has been changing its course since the past $15-20$ years, posing a risk to monsoon season crops. In the recent past, more than 100 bigha $\left(1337 \mathrm{~m}^{2}\right)$ of land are being affected by sedimentation along the river bank in the Dhankauli village. Flood-induced river cutting and deposition of sand and gravel in agricultural field have become severe problem in the field near river bank in Kapilvastu. Belgurduwa river (previously called Gurung Khola) has created the same in the Barakulpur VDC.

The farmers have left to grow cereals like paddy and have started cultivating Arachis hypogaea (groundnut/peanut) in Barakulpur. Jyoti and B-4 are the highest yielding varieties that becomes ready for harvesting in 140 days. Sandy loam soil, which is near river eroded area, is suitable for peanuts. Farmers located along the river banks in the Terai region cultivate Citrullus lanatus (Watermelon) and Ipomoea batatas (Sweet potato) in the river banks during winter (JanuaryFebruary), also known as bagar farming (Baluwa kheti).

Therefore, farmers have adopted Bagar farming of Arachis hypogaea (groundnut/peanut) as an alternative to cereals. Cercospora arachidicola Hori (Early leaf spot) and Phaeoisario psis personata Berk. Curt (late leaf spot) are the common disease that are observed during the study. The introduction of Arachis hypogaea (groundnut/peanut), Citrullus lanatus (Watermelon) and Ipomoea batatas (Sweet potato) along the river banks, also known as Bagar farming, protects the land from excessive degradation.

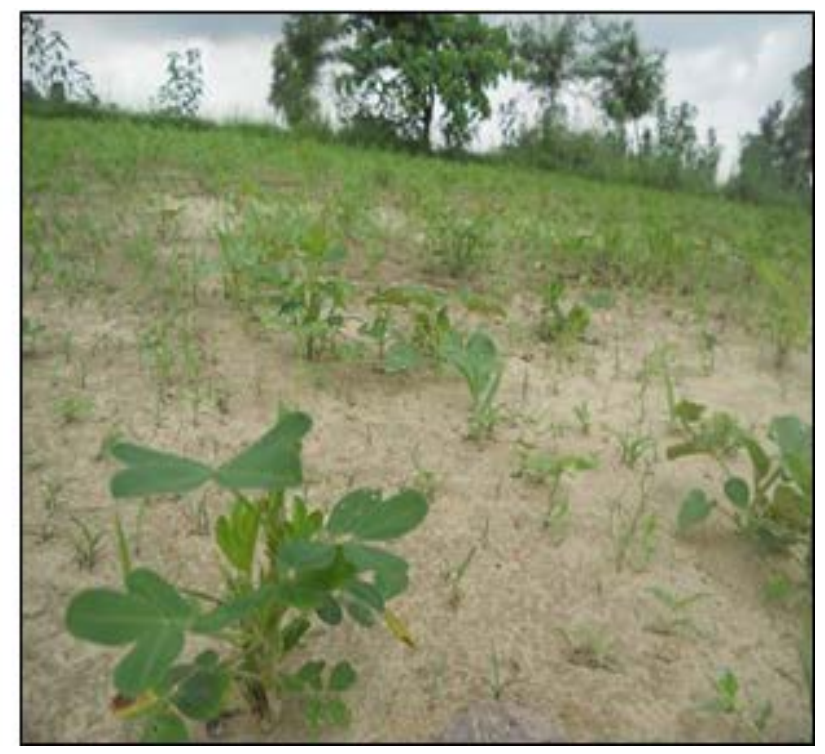

Figure 7. Left and Right. Bagar farming of Groundnut

\subsection{Conservation of Marhatte Pond by the Community}

It is observed in Barakulpur, Kapilvastu. Community of Barkalpur VDC are suffering from erratic rainfall. Similarly, inadequate water at the time of fruiting of maize, has lead to decrease in crop yield substantially. In order to address water scarcity problem, Siddhartha Community Forest (SCF) constructed dam in Marhatte pond through its own effort in 2008 to conserve water and use for irrigation purposes. Rainwater is collected in this pond and is used to irrigate 150-200 bigha of land in different villages of Barkalpur. People use the same pond for fishing purpose in order to uplift their economic status. Farmers believe that conservation of forests is essential to recharge ground water, control erosion and consequently, reduce siltation in rivers and to protect fisheries as well. For the conservation of pond the community conduct clean up campaign once in a year and remove weeds of the pond. 

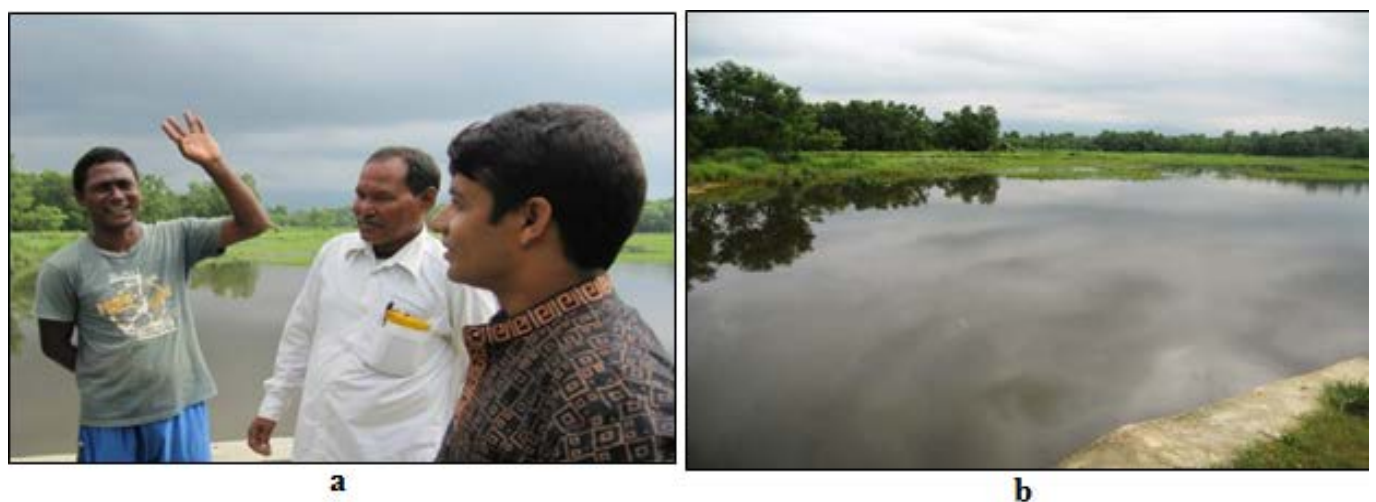

Figure 8. a. Interview with local farmer at Marhatee lake; b. Marhatee pond and SCF

\subsection{Raise Foundation of House}

It is observed in Dhankauli, Kapilvastu. Every year during monsoon Dhankauli VDC gets inundated with rainwater due to flash flood in a Bel river. Flood water enter inside the house and cause loss of lives and property. Higher intensity and frequency of rainfall cause huge damage every year and hundreds of family members are affected.

To resolve this people have raised a foundation of house with mud and has constructed at a greater height so that the house isn't submerged with flood. But this practice isn't feasible during heavy rainfall as the house gets inundated. In such case, the people leave the place with their family members and moves to a safer place, or stay at relatives and landlord's house.

\section{Conclusion}

Impacts of climate change are inevitable and the most vulnerable mountainous country like Nepal is more affected due to low adaptation capacities of the rural communities. Climate change is the crosscutting issue and its impacts have been reported in all the sectors and particularly more on rural farmers whose livelihood depends on agriculture farming. Local knowledge, practices and innovations are important elements for community-based coping and adaptation mechanisms. There was limited awareness, knowledge and capacity at local level to understand climate change scenarios, address issues, and conduct long-term planning. Coping strategies and adaptation mechanism were limited at the study site. However, there were few examples of adaptation strategies in agriculture such as conservation of water resources, change in cropping patterns, choice of crops and shift from agriculture to forestry and animal husbandry. Study found that temperature of Kapilbastu district has increasing trend and rainfall is unpredictable with increasing drought periods and two to three weeks delayed monsoon with less numbers of rainy days that has resulted loss of species, declining productivity and yield, outbreak of diseases and pests.

Therefore, climate change impacts and adaptation measures are the two major options that the government of Nepal should concentrate on urgently. Moreover, future research should focus on identifying the climate change impacts at local, regional and national level for developing coping strategies and adaptation mechanism to minimize the impacts of climate change in Nepal.

\section{Acknowledgement}

The authors would like to thank to the MultiStakeholders Forestery Program (MSFP), Youth Network for Social and Environment Development (YONSED), Ministry of Agriculture and Cooperatives (MoAC) and Central Bureau of Statistics (CBS) Nepal for helping to carry out this research. The author wishes to thank parents and family members for their encouragement and inspiration through out the whole study.

\section{References}

[1] Alan M, Regmi BR. Adverse Impacts of Climate Change on Development of Nepal: Integrating Adaptation into Policies and Activities. Capacity Strengthening of Least Developed Countries for Adaptation to Climate Change (CLACC); 2005.

[2] Aydinalp C, Cresser MS. The effects of global climate change on agriculture. Am. Eurasian J. Agr. Envrion. Sci. 2008; 3(5): 672681.

[3] Baidya SK, Shrestha ML, Seikh MM. Trends in daily temperature and precipitation in Nepal. Journal of Hydrology and Meteorology.2008; Vol (5)1; 38-51.

[4] Bartlett R, Bharati L, Pant D, Hosterman H, McCornick P. Climate change impacts and adaptation in Nepal. International Water Management Institute (IWMI) Working Paper no 139, Colombo, Sri Lanka; 2010.

[5] Chapagain BK, Subedi R, Paudel NS. Exploring local knowledge of climate change: some reflections. J. Agric. Environ. 2009; 8(1): 106-120.

[6] Charmakar S. Exploring existing local adaptation practices and potential strategic options to address climate change impact on biodiversity and its dependents of Nepal. National Adaptation Programme of Action/ Ministry of Environment. Kathmandu, Nepal; 2010.

[7] Dulal HB, Brodnig G, Thakur HK, Green-Onoriose C. Do the poor have what they need to adapt to climate change? A case study of Nepal. Local Environ. 2010; 15(7): 621-635.

[8] Dyurgerov MD, Meier MF. Glaciers and changing earth system: a 2004 snapshot. Institute of Arctic and Alpine Research. University of Colorado; 2005.

[9] Government of Nepal (GON). Initial National Communication to the COP of UNFCC. Kathmandu: Ministry of population \& Environment, Government of Nepal; 2004.

[10] Gurung GB, Bhandari D. Integrated Approach to Climate Change Adaptation. Journal of Forest and Livelihood.2009; 8(1): 91-99.

[11] Intergovernmental Panel on Climate Change (IPCC). Climate Change 2007: Impacts, Adaptation and Vulnerability. Contribution of Working Group II to the Fourth Assessment Report of the IPCC. Parry ML, Canziani OF, Palutikof JP, van der 
Linden PJ, Hanson CE; Eds. Cambridge: Cambridge University Press; 2007.

[12] Keane J, Page S, Kergna A, Kennan J. Climate change and developing county agriculture: An overview of expected impacts, adaptation and mitigation challenges, and funding requirements. ICTSD-IPC Platform on climate change, agriculture and trade. Issue brief no 2. International Centre for Trade and Sustainable Development. Switzerland and International Food \& Agricultural Trade Policy Council. USA; 2009.

[13] Khanal RC. Climate change and organic agriculture. J. Agric.Environ. 2009; 10(1):100-110.

[14] Liu SY, Ding YJ, Li J, Shangguan DH, Zhang Y. Glaciers in response to recent climate warming in Western China. Quaternary Sciences; 2006. p. 762-771.

[15] Lohani SN. Climate change in Nepal-shall we wait until bitter consequences? J. Agric. Environ. 2007; 8(1): 38-45.

[16] Lybbert TJ, Sumner DA. Agricultural technologies for climate change in developing countries: Policy options for innovation and technology diffusion. Food Policy; 2012. p. 114-123.

[17] Malla G. Climate Change and its Impact on Nepalese agriculture. The Journal of Agriculture and Environment. 2008; 9:62-71.

[18] Manandhar S, Schmidt VD, Perret S, Kazama F. Adapting cropping systems to climate change in Nepal: a cross-regional study of farmers' perception and practices Reg. Environ. Change; 2011. p. 335-348.

[19] Ministry of Finance (MOF). Economic Survey: fiscal year 2010/11. Government of Nepal. MOF. Nepal; 2011.

[20] National Adaptation Programmeme of Action (NAPA) $\backslash$ Ministry of Environment (MOE). NAPA to Climate Change. MOE. Nepal; 2010.

[21] Nepal Climate Vulnerability Study Team (NCVST). Vulnerability Through the eye of Vulnerable: Climate Change Included Uncertainties and Nepal's Development Predicaments. Institute for Social and Environmental Transition (ISET). Kathmandu; 2009.
[22] Practical Action. Understanding Disaster Management in Practice: with reference to Nepal. Kathmandu, Nepal: Practical Action; 2010.

[23] SAGUN. Climate Change Impacts on Livelihoods of Poor and Vulnerable Communities and Biodiversity Conservation: A Case Study in Banke, Bardia, Dhading and Rasuwa District of Nepal. Strengthened Actions for Governance in Utilization of Natural Resources Program. CARE Nepal. Kathmandu, Nepal; 2009. p. 56.

[24] Shrestha AB, Wake CP, Dibb JE, Mayewski PA. Precipitation fluctuations in the Nepal Himalaya and its vicinity and relationship with some large scale climatological parameters. International Journal of Climatology. 2000; 20(3): 317-327.

[25] Shrestha UB, Gautam S, Bawa KS. Widespread Climate Change in the Himalayas and Associated Changes in Local Ecosystems. PLoS ONE. 2012; 7(5): e36741.

[26] Shrestha AB, Wake CP, Mayewski PA, Dibb JE. Maximum Temperature Trends in the Himalaya and its Vicinity: An Analysis Based on Temperature Records from Nepal for the Period 1971-94. Journal of Climate. 1999; (12): 2775-2789.

[27] UNFCCC. The First Ten Years. Climate Change Secretariat. Bonn, Germany; 2004.

[28] Upreti DC. Rising Atmospheric CO and Crop Response. SASCOM Scientific Report; 1999.p.1-8.

[29] WFP. The Cost of Coping. A Collision of Crises and the Impact of Sustained Food Security Deterioration in Nepal. United Nations World Food Progarmme. Nepal Food Security Monitoring System; 2009.

[30] WWF Nepal. Landslide hazard zonation mapping and vulnerability assessment along the trekking route from Ghat to Manjo in Solukhumbu district Sagarmatha National Park and buffer zone area; 2008.

[31] Zemp M, Roer I, Kaab A, Hoelzle M, Paul F, Haeberli W. Global glacial changes: facts and figures. World Glacier Monitoring Service. Zurich, Switzerland; 2008. 